Primljen / Received: 16.2.2016. Ispravljen / Corrected: 11.7.2016. Prihvaćen / Accepted: 12.8.2016. Dostupno online / Available online: 10.12.2016.

\section{Nonlinear seismic analyses of historical Topuzlu Dam under different seismic loads}

Authors:

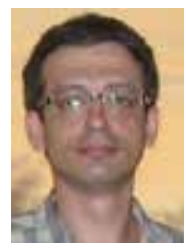

Assist.Prof. Erkut Sayın, PhD. CE

Fırat University, Elazığ, Turkey

Faculty of Engineering

Department of Civil Engineering

erkutsayin@gmail.com

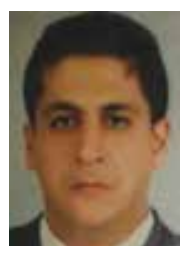

Assoc.Prof. Muhammet Karaton, PhD. CE

Fırat University, Elazığ, Turkey

Faculty of Engineering

Department of Civil Engineering

mkaraton@firat.edu.tr

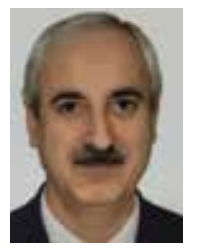

Prof. Yusuf Calayır, PhD. CE

Fırat University, Elazığ, Turkey

Faculty of Engineering

Department of Civil Engineering

ycalayir@firat.edu.tr

\section{Erkut Sayın, Muhammet Karaton, Yusuf Calayır}

\section{Nonlinear seismic analysis of historical Topuzlu Dam under different seismic loads}

The nonlinear analysis of historical Topuzlu Dam under various seismic loads is presented in this study, taking into account the solid-fluid interaction. The smeared crack model, which includes strain softening, is used to examine nonlinear behaviour of the dam material. The reservoir and soil domains are assumed to be linearly elastic. The ANSYS finite element program is used for generation of solutions.

\section{Ključne riječi:}

solid-fluid interaction, smeared crack model, artificial accelerograms, nonlinear seismic analysis

Stručni rad

\section{Erkut Sayın, Muhammet Karaton, Yusuf Calayır}

\section{Nelinearna seizmička analiza povijesne brane Topuzlu pri seizmičkom} opterećenju različitih razina

U radu je obrađena nelinearna analiza povijesne brane Topuzlu pri seizmičkom opterećenju različitih razina, uzimajući u obzir međudjelovanje čvrstog tijela i tekućine. Za analizu nelinearnog ponašanja materijala od kojeg je brana izgrađena koristi se model razmazanih pukotina koji uključuje omekšavanje pri deformaciji. Pretpostavljeno je da su domene akumulacije i tla linearno elastične. Za generiranje rješenja oblikovani su modeli konačnih elemenata u programskome paketu ANSYS.

\section{Ključne riječi:}

interakcija čvrstog tijela i tekućine, model razmazanih pukotina, umjetni akcelerogrami, nelinearna seizmička analiza

Fachbericht

\section{Erkut Sayın, Muhammet Karaton, Yusuf Calayır}

\section{Nichtlineare seismische Analyse des historischen Damms Topuzlu bei} seismischen Einwirkungen

In dieser Arbeit wird die nichtlineare Analyse des historischen Damms Topuzlu bei seismischen Einwirkungen verschiedener Intensitäten bearbeitet. Dabei wird die Interaktion zwischem dem steifen Körper und der Flüssigkeit berücksichtigt. Bei der Analyse des nichtlinearen Verhaltens wird für das Material, aus dem der Damm besteht, ein Modell verschmierter Risse mit Enthärtung bei Verformungen angesetzt. Es wird angenommen, dass die Domänen der Akkumulation und des Bodens linear elastisch sind. Um die Ergebnisse zu generieren, wurden im Programm ANSYS finite Elemente Modelle erstellt.

Ključne riječi:

Interaktion steifer Körper und Flüssigkeiten, Modell verschmierter Risse, künstliche Beschleunigungszeitverläufe, nichtlineare seismische Analyse 


\section{Introduction}

Historical artefacts are structures that serve as a bridge between the past and the present. Historical dams constitute a part of historical heritage of our country. Dams are constructed mostly for the purposes of irrigation or for potable water supply. Earthquakes rank among the most significant problems with regard to protection of historical artefacts. The seismic behaviour of historical structures should be determined and necessary precautions should be taken so as to ensure that these structures suffer the least possible earthquake damage, and to preserve their structural integrity.

Three different modelling methods, i.e., detailed micro-modelling, simplified micro-modelling, and macro-modelling, are used, depending on the sensitivity level and the requested simplicity with regard to masonry modelling [1]. The macro-modelling method is commonly preferred for modelling large scale masonry structural systems because this method decreases the computer use time significantly [2, 3]. Fanning and Boothby [4] analysed three masonry bridges under static loads by modelling them using the macro-modelling method. They used the smeared crack model for load-bearing structural elements. Bernardeschi et al. [5] examined the Buti Bell Tower in Italy under two different conditions through macro-modelling, i.e. under its own weight and under horizontal load effects other than its own weight. Karaton et al. [6] evaluated the non-linear seismic behaviour of the historical Malabadi Bridge using the acceleration records of the 1992 Erzincan earthquake. Bayraktar et al. [7] generated a finite elements model of the Haghia Sofia Bell Tower in Trabzon using the macro-modelling method, and they performed a non-linear dynamic analysis under the east-west component of the 1992 Erzincan earthquake. Sayın et al. [8] modelled the historical Uzunok Bridge in Malatya using the macro-modelling method, and performed linear and non-linear seismic analyses of the bridge. They used the 2003 Bingöl earthquake acceleration records as the seismic effect. Gonen et al. [9] investigated stresses and deformations of a historical masonry arch bridge under dead loads via the macro-modelling approach. The linear elastic response of the bridge was investigated.

The dam-soil and reservoir interaction problems are assumed to involve the fluid-solid interaction. The interaction may be modelled by the Eulerian approach, Lagrangian approach, or Westergard approach. In the Eulerian approach, the solid and fluid domains have displacement and hydrodynamic pressure freedoms, respectively. Therefore, the interface transformation elements must be used for both domains. However, both the solid and fluid domains have displacement freedom in the Lagrangian approach. Thus, special interface elements are not required for the interaction. In the Westergard approach, the reservoir domain is assumed to be the masses that were added to the upstream of the dam.
Non-linear analyses of the historical Topuzlu (Sultan Mahmud I) Dam are performed in this study taking into account the solidfluid interaction. The seismic behaviour of the dam is evaluated by comparison of results. The smeared crack model, which accounts for the strain softening, is used to evaluate nonlinear behaviour of the dam material. The reservoir and soil domains are assumed to be linearly elastic. The solid-fluid (dam and soilreservoir) interaction is considered using the Euler's approach. The artificial earthquake acceleration data conforming to the design acceleration spectrum given in the Turkish Seismic Code for Coastal and Harbour Structures (DLH'2007) are generated as the seismic effect. The combined form of the generalized $\alpha$ and predict-correct methods is used for dynamic analyses [11].

\section{Numerical modelling of masonry structures}

Depending on the level of accuracy, three modelling approaches are commonly used for modelling masonry structures. These approaches (detailed micro, simplified micro, and macro) are given in Figure 1 [1].

In the detailed micro-modelling, the material specifications of the masonry units and the mortar, i.e., the modulus of elasticity, Poisson ratio, and density, are evaluated separately. The masonry units are widened by as much as half of the mortar layer in the simplified micro-modelling. Thus the mortar layer is neglected, and the masonry units are separated from each other with interface lines. Macro-modelling is an equivalent material model that assumes the construction elements to be a composite without any exception among stone, brick and mortar. When the literature is reviewed, it can be seen that macro-modelling is used to model large-scale historical structures because of its reduced computer solution time. In this study, the dam is modelled by means of the macro-modelling approach.

One of the fracture and damage mechanics methods might be used for modelling damage/cracking in material. In the fracture mechanics, a crack in the material can be modelled using two different crack approaches, i.e., the local (smeared crack) and global (discrete crack) approaches. The smeared crack approach is based on rearrangement of the matrix that connects the stresses and strains depending on description of a weak surface in the direction normal to the tensile stress. The damage mechanics is a local approach that is based on the same philosophy as the smeared crack model $[12,13]$. In the discrete crack approach, cracks are modelled with the description of a discontinuous region in a continuum domain,

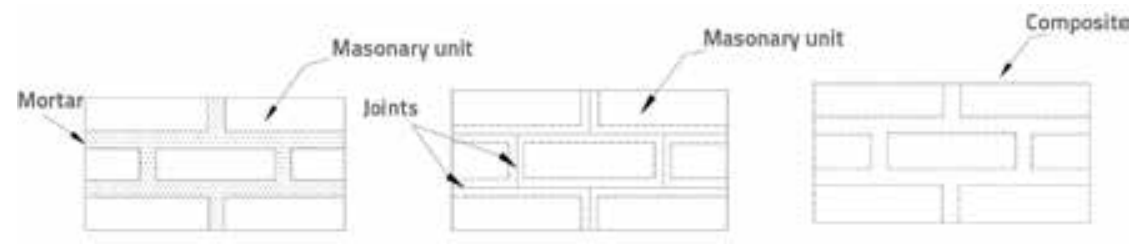

Figure 1. Modelling approaches for masonry structures: a) Detailed micro-modelling; b) Simplified micro-modelling; c) Macro-modelling 

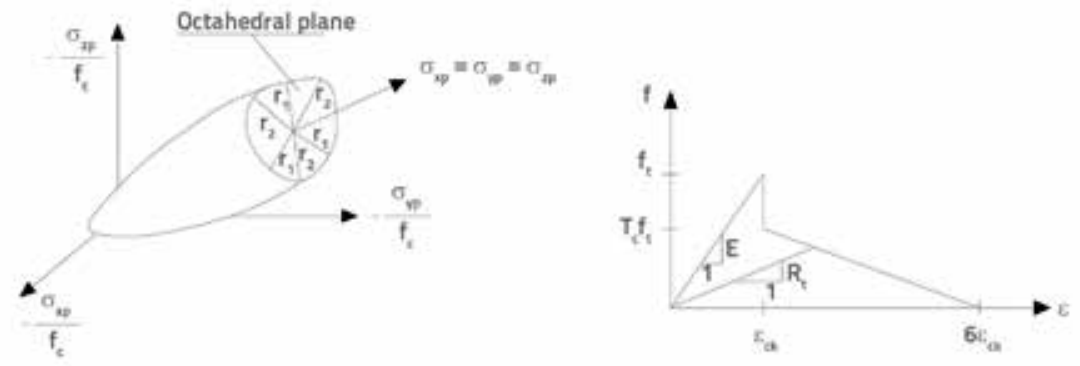

force, respectively, for the same system. $\{P\}$ is the hydrodynamic pressure vector, and $\{\dot{P}\}$ and $\{\ddot{P}\}$ represent once and twice partial derivatives of this vector. The quantities of $\left[K_{f}^{P}\right],\left[M_{f}^{P}\right]$ and $\left[C_{f}^{P}\right]$ are coefficient matrices of the vectors $\{P\},\{\dot{P}\}$ and $\{\ddot{P}\}$, respectively. $\left\{F_{f g}\right\}$ is the fluid load vector occurring due to rigid acceleration at the fluid-solid interface. $[R]$ is the transformation matrix at the fluid-solid interface, which is used in determining the fluid load vector due

to accelerations of the solid medium and

Figure 2. Three-parameter concrete model: a) Yield surface; b) uniaxial stress-strain relationship

and the stress is calculated according to the theories of fracture mechanics. In this study, Solid 65 concrete element is used in ANSYS program for cracking and crushing of masonry units. The cracking and crushing in the element is taken into account in the smeared crack approach. This element was used in the macro-modelling of masonry structures [4]. As can be seen in Figure 2.a, the yield surface of the element is the William and Warnke [14] yield surface, and it has an octahedral plane. In this figure, symbols $\sigma_{x p^{\prime}} \sigma_{y p}$ and $\sigma_{z p}$ stand for orthogonal principal stresses, and $\mathrm{f}_{\mathrm{c}}$ represents the uniaxial compressive strength of the material. As shown in Figure 2.b, the idealized curve is given for the uniaxial stress-strain relation of a material. In this figure, $f_{t}$ is the uniaxial tensile strength of the material, $E$ is the initial elasticity modulus and $\varepsilon_{c k}$ is the cracking threshold strain. $T_{c}$ is the reduction coefficient for the tensile strength after cracking threshold strain and $R_{t}$ is the secant elasticity modulus in the crack softening region. The ultimate strain is also limited as $6 \varepsilon_{c k}$.

\section{Eulerian formulation for fluid-solid dynamic interaction systems}

Three-dimensional wave equation for the linearly elastic, inviscid and irrotational fluid with small amplitude is presented by Zeinkiewicz and Taylor [15]:

$P_{y_{x x}}+P_{y_{y y}}+P_{y_{z z}}=\frac{1}{C^{2}} \ddot{P}$

where $\mathrm{P}$ is the hydrodynamic pressure, while $P_{\mathrm{r}_{\mathrm{x} x^{\prime}}} P_{\mathrm{r}_{\mathrm{y}} \mathrm{y}^{\prime}} P_{\mathrm{r}_{\mathrm{zz}}}$ and $\ddot{P}$ are the twice partial derivative of the hydrodynamic pressure with respect to the $x$ axis, $y$ axis, $z$ axis, and time, respectively. $C$ is the pressure wave velocity of the fluid. The equations of motion of the fluid-solid system subjected to dynamic excitation may be given as shown by [16]:

$\left[M_{s}\right]\left\{\ddot{U}_{s}\right\}+\left[C_{s}\right]\left\{\dot{U}_{s}\right\}+\left\{F_{s}^{\text {int }}\right\}+\left[K_{s f}\right]\{P\}=\left\{F_{s}\right\}$

$\left[M_{f s}\right]\left\{\ddot{U}_{s}\right\}+\left[M_{f}^{P}\right]\{\ddot{P}\}+\left[C_{f}^{P}\right]\{\dot{P}\}+\left[K_{f}^{P}\right]\{P\}=\left\{F_{f g}\right\}$

where $\left[M_{s}\right]$ and $\left[C_{s}\right]$ represent the mass and damping matrices for the solid domain, respectively. $\left\{\ddot{U}_{s}\right\},\left\{\dot{U}_{s}\right\},\left\{F_{s}^{\text {int }}\right\}$ and $\left\{F_{s}\right\}$ are the vectors of relative acceleration, relative velocity, internal force and external the extra solid loads due to pressures of the fluid domain. The quantities of $\left[M_{f s}\right]$ and $\left[K_{f s}\right]$ can be expressed as:

$\left[M_{f s}\right]=\rho[R]$

$\left[K_{s f}\right]=-[R]^{T}$

where $\rho$ is the mass density of fluid domain.

\section{Nonlinear seismic analyses of historical Topuzlu Dam}

Nonlinear seismic analyses of Topuzlu Dam were performed in this study by considering the dam-soil-reservoir interactions. The dams of the Taksim water-supply facilities were constructed on the Acıelma affluent, which is one of tributaries of the Kâğıthane Stream. The construction of three dams forming the Taksim water-supply facilities started by building Topuzlu Dam. The water supplied to the city did not satisfy the city's need after 1731 , when the distribution line of Taksim water-supply facilities came into service. Subsequently, Topuzlu Dam was constructed on the Eskibağlar affluent of the Acıelma stream in Bahçeköy by Sultan Mahmud I in 1750. Topuzlu Dam was constructed as a masonry dam, shaped as a broken arch between two large buttresses (Figure 3). The hydrologic area occupied by the dam extends to $920000 \mathrm{~m}^{2}$, the height of the tallest section of the dam is $12.75 \mathrm{~m}$, the crest length is $63.05 \mathrm{~m}$, and the lake volume is $160000 \mathrm{~m}^{3}$ [17].

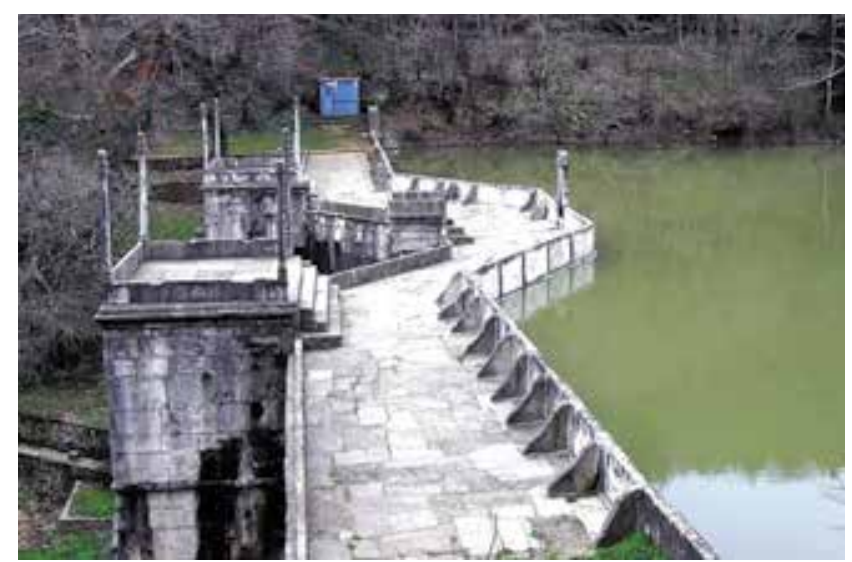

Figure 3. Topuzlu Dam 
The dam is modelled using the macro-modelling approach. The smeared crack model, which accounts for strain softening, is used for the nonlinear material behaviour. It is accepted that the reservoir and soil domains show linearly elastic behaviour. The solid-fluid interaction is modelled based on the Eulerian approach. The plan layout and the tallest section of the dam are given in Figure 4. The three-dimensional finite element model of the dam is shown in Figure 5. Overall, 15701 nodal points and 13333 quadrilateral prismatic elements are used in the finite element model. The nodal point 6035 on the crest of the dam is also shown in the figure. As to seismic effect, artificial earthquake acceleration data are produced for each of the earthquake levels D1, D2, and D3, which are compatible with the design acceleration spectrum given in DLH'2007, taking into account seismic characteristics of the region in which Topuzlu Dam is located. The D1 level represents low-magnitude earthquakes and it exhibits a high probability of occurrence during service life of structures. The exceedance probability of this earthquake level is $50 \%$ in 50 years, and its return period is 72 years. The D2 level represents large earthquakes that do not have a strong possibility of occurrence during service life of structures. The probability of exceedance of this earthquake level is $10 \%$ in 50 years, and its return period is 475 years. The D3 level represents strongest earthquakes to which structures could be exposed. It exhibits a low probability of occurrence during service life of structures. The exceedance probability of the earthquake is $2 \%$ in 50 years, and its return period is 2475 years. A partition of 11 seconds of the artificial acceleration data is considered, and these data are applied in the (-y) direction of the dam-soil-reservoir system for the D1, D2 and D3 earthquake levels. Thus, nonlinear seismic analyses of the dam were made for these earthquake levels. The SMS is the maximum spectral acceleration value, and SM 1 is the spectral acceleration value corresponding to $1.0 \mathrm{~s}$ period. Table 1 shows reference SMS and SM1 values (DLH-2007) that are used to generate artificial acceleration data for the D1, D2 and D3 earthquake levels. The artificial acceleration data are generated so as not to exceed $5 \%$, which is the mean difference between the reference and artificial acceleration spectra. The artificial and reference acceleration spectrum curves are given in Figure 6 for the earthauake levels D1. D2. and D3.

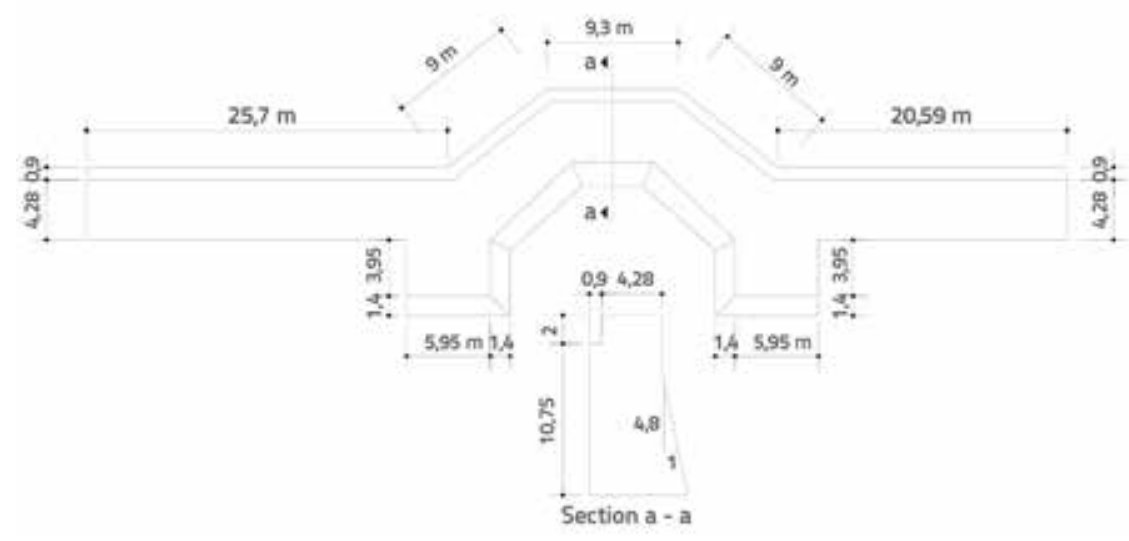

Figure 4. Plan layout and tallest dam section

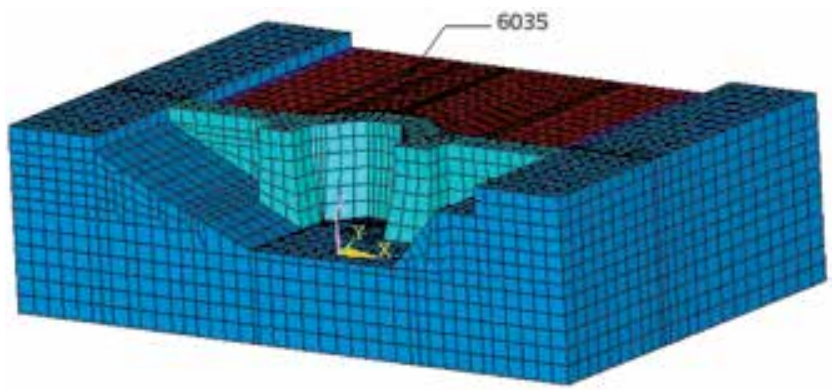

Figure 5. Three-dimensional finite element model of historic Topuzlu Dam

The absolute maximum amplitude values of the artificial earthquake acceleration data for the D1, D2 and D3 earthquake levels amount to $0.1986 \mathrm{~g}, 0.3370 \mathrm{~g}$ and $0.4342 \mathrm{~g}$, respectively. Graphics for these acceleration data are shown in Figure 7. The generalized algorithm, conducted based on the predict-correct method, is used for the seismic analyses.

Theelasticitymodulus, mass density, Poisson ratio, tensile strength, and compressive strength values of the dam material amount to $7.5 \times 10^{3} \mathrm{MPa}, 2.2 \mathrm{t} / \mathrm{m}^{3}, 0.25,1.0 \mathrm{MPa}$, and $10 \mathrm{MPa}$, respectively $[2,3,4,5,7]$. The soil domain is assumed to be massless in the solutions, and the modulus of elasticity and Poisson ratio of the soil domain amount to $3 \times 10^{4} \mathrm{MPa}$ and 0.20 , respectively (C class soil, DLH'2007). The mass density and bulk modulus of the reservoir domain are taken to be $1.0 \mathrm{t} / \mathrm{m}^{3}$ and $2070 \mathrm{MPa}$, respectively. The tensile strength reduction coefficient after the crack amounts to 1.0. The rigidity proportional viscous damping is used in the solid domain. The natural frequency of effective mode for the dam-soil system in stream direction is $16.4521 \mathrm{~Hz}$. The rigidity proportional damping coefficient of the dam-soil system is calculated to provide $5 \%$ damping ratio at this frequency.

Table 1. Reference $S_{\mathrm{MS}}$ and $\mathrm{S}_{\mathrm{M} 1}$ values for three earthquake levels

\begin{tabular}{|c|c|c|c|}
\hline $\begin{array}{l}\text { Rarthquake level } \\
\text { Reference } \\
\text { value }\end{array}$ & D1 & D2 & D3 \\
\hline $\mathrm{S}_{\mathrm{MS}}$ & 0,5520 & 0,6900 & 0,7756 \\
\hline $\mathrm{S}_{\mathrm{M} 1}$ & 0,2800 & 0,3500 & 0,5075 \\
\hline
\end{tabular}

The integration step is selected as 0.001 sec. to prevent sudden crack propagation. The maximum iteration number 40 is also selected. The ANSYS finite element program is used to obtain solutions. Nonlinear seismic solutions for the damsoil-reservoir system are obtained using the artificial earthquake acceleration data generated for three different earthquake levels. As a result of these solutions, the time-history graphics have been developed for the nodal point 6035 (stream direction), which is located at the central region of the dam crest, as shown in Figure 8. 

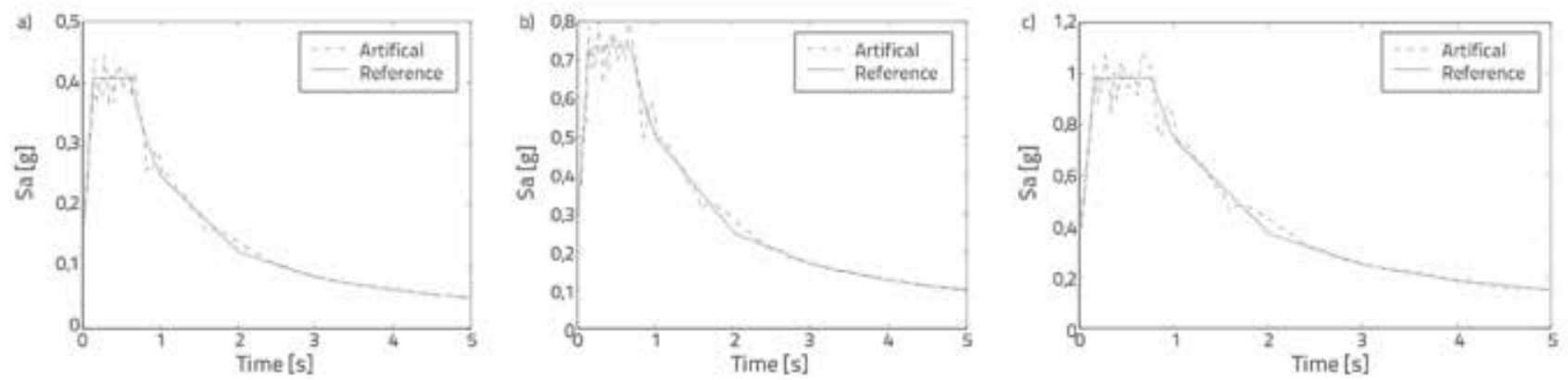

Figure 6. Artificial and reference acceleration spectrum curves for earthquake: a) level D1; b) level D2; c) level D3
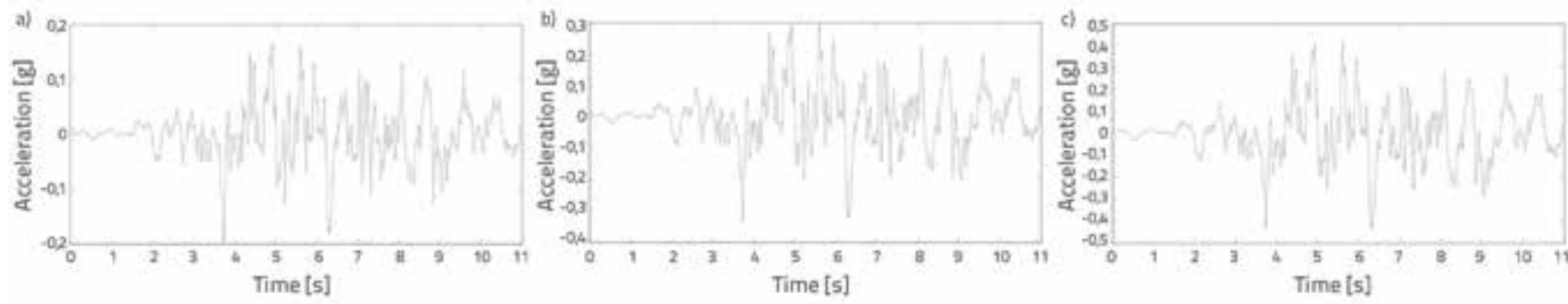

Figure 7. Artificial earthquake acceleration data-time graphs generated for: a) earthquake level D1; b) earthquake level D2; c) earthquake level D3
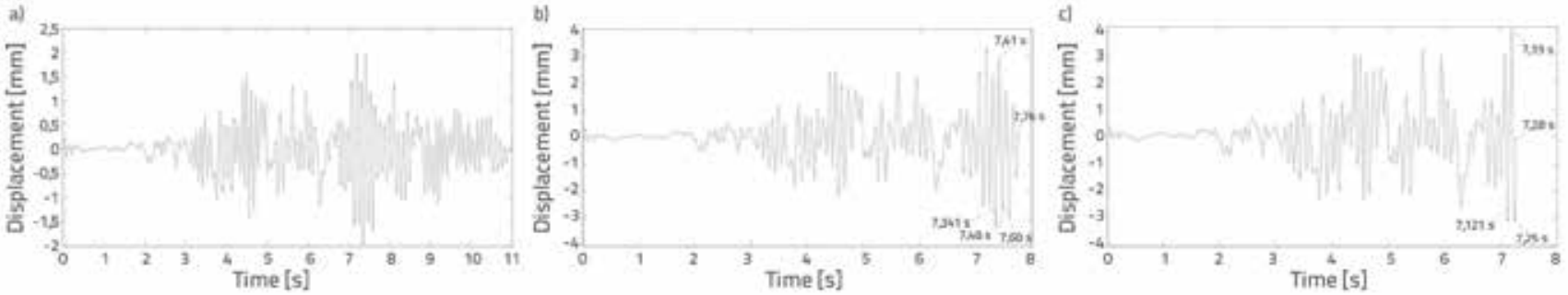

Figure 8. Time history displacement of nodal point 6035 in the direction of the stream: a) earthquake level D1; b) earthquake level D2; c) earthquake level D3

The solutions obtained for the D1 earthquake level continued for 11 seconds, and the earthquake did not cause any damage to the dam. The absolute maximum value of displacement for the D1 earthquake level was obtained at approximately $2 \mathrm{~mm}$. In the analyses for the D2 and D3 earthquake levels, the maximum iteration number was also exceeded, and the solutions did not converge due to cracking that occurred in the dam. The absolute maximum displacement values for the D2 and D3 earthquake levels were obtained as 3.32 and $3.92 \mathrm{~mm}$, respectively. The numbers noted on the time history graphs (Figures 8.b and 8.c) are indicative of the times of cracking and propagation of cracking zones in the dam.

In the investigation of cracking and propagation of cracking zones at such earthquake levels, the dam was not damaged at the D1 earthquake level. However, the first damage for the D2 earthquake level was obtained in the region where the rightand left-side buttress walls connect with the soil, at $7.341 \mathrm{~s}$. This cracking case is shown in Figure 9.a. These cracking zones occurred as a result of the dam crest motion in the direction opposite to the stream flow. Propagations were observed in these crack regions at $t=7.41 \mathrm{~s}$ due to motion of the dam crest in the stream direction (Figure 9.b). The dam crest moved in the direction opposite to the flow, and a further increase was observed at such crack regions (Figure 9.c). Propagations in the crack region at the right-side buttress wall of the dam were observed at $t=7.48 \mathrm{~s}$ (Figures 10.a and 10.b). The solutions could not converge due to crest motion in the stream direction at $\mathrm{t}=7.76 \mathrm{~s}$.

The first damage for the D3 earthquake level was obtained in the region where the right- and left-side buttress walls connect
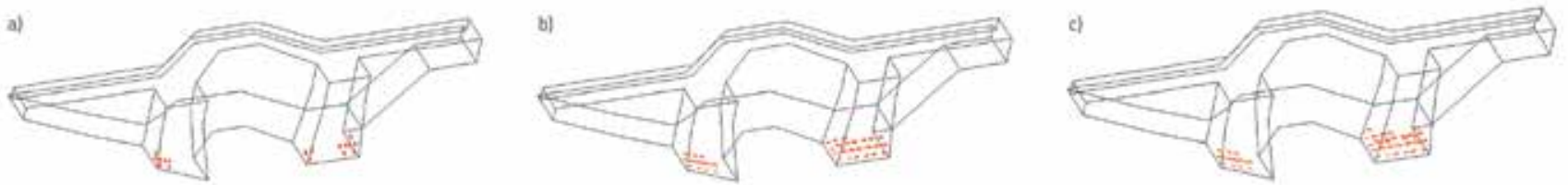

Figure 9. Dam cracking at different time steps for earthquake level D2: a) $t=7,341 \mathrm{~s} ; \mathrm{b}) \mathrm{t}=7,41 \mathrm{~s} ; \mathrm{c}) \mathrm{t}=7,48 \mathrm{~s}$ 

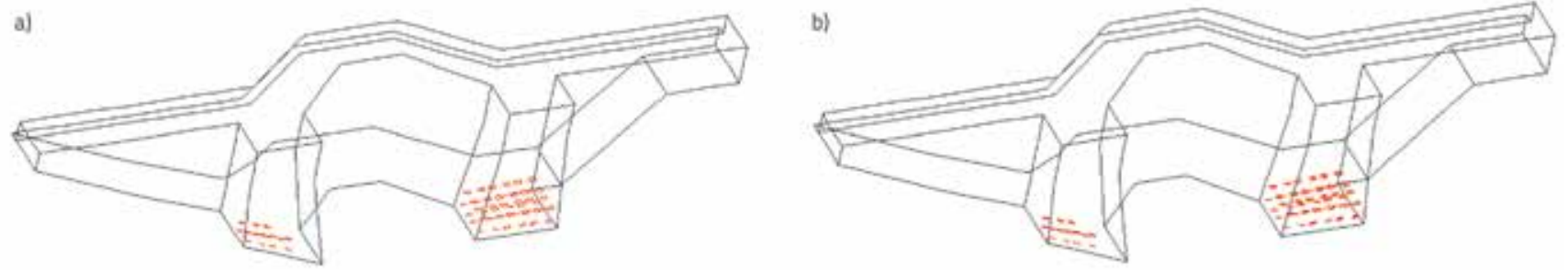

Figure 10. Dam cracking cases at D2 earthquake level: a) $t=7,60 \mathrm{~s} ; \mathrm{b}) \mathrm{t}=7,76 \mathrm{~s}$
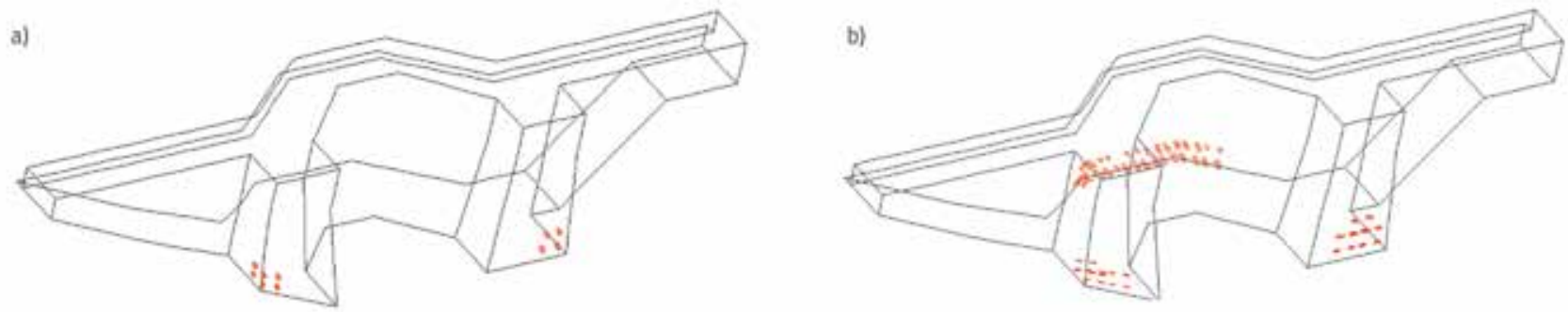

Figure 11. Dam cracking cases at D3 earthquake level: a) $t=7,121$ s; b) $t=7,19$ s

a)

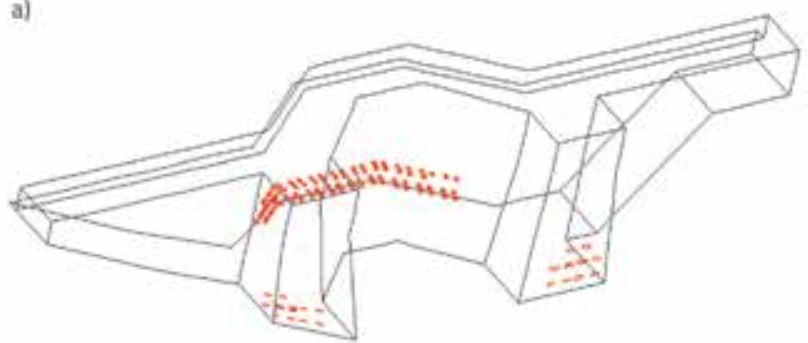

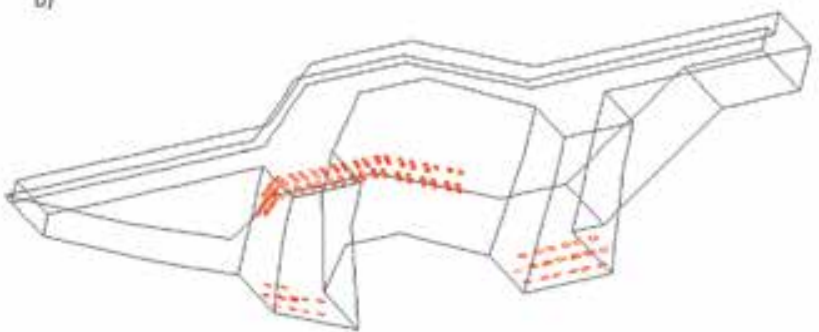

Figure 12. Dam cracking cases at D3 earthquake level: a) $t=7,25 \mathrm{~s}$; b) $t=7,28 \mathrm{~s}$

with the soil, at $7.121 \mathrm{~s}$ (Figure 11.a). These cracking zones occurred as a result of motion of the dam crest in the direction opposite to the flow. A new crack region was obtained in the connected region, in which the soil with the middle of the dam was in the upstream face due to motion of the dam crest in the stream direction at $t=7.19 \mathrm{~s}$ (Figure 11.b). In addition, propagations in the crack regions occurred at the buttress walls (Figure 11.b).

In the direction opposite to the stream flow, the cracks in the upstream of the dam were propagated at $7.25 \mathrm{~s}$ (Figure 12.a). After this time step, the propagations in the crack region in the right-side buttress were observed to depend on the dam crest displacement in the direction of the stream flow. The analysis was finished because convergence in the iterations could not be provided at $7.28 \mathrm{~s}$ (Figure 12.b).

\section{Conclusion}

Non-linear seismic analyses of the historical Topuzlu Dam, which is one of the dams of the Taksim water-supply facilities, were performed in this study by considering the dam-soilreservoir interactions. A three-dimensional finite element model of the dam was generated using the macro-modelling method. The smeared crack model, which considers strain softening, was used as the material model. It was accepted that the reservoir and soil domains exhibit linear elastic behaviour. The solid-fluid interaction was considered using the Euler's approach. The artificial earthquake acceleration data were generated for three different earthquake levels, D1, D2, and D3, taking into account seismic characteristics of the region in which Topuzlu Dam is located. The combined form of the generalized $\alpha$ and the predict-correct methods was used for dynamic analyses. No cracks occurred at the dam for the artificial earthquake data that were obtained at the D1 earthquake level. The cracks occurred in the regions where the right- and left-side buttresses of the dam connected to the soil at the D2 earthquake level. The analysis was completed because convergence could not be provided in the iterations at $7.76 \mathrm{~s}$. For the D3 earthquake level, the cracks occurred in the regions where the right and left-side buttresses of the dam and the upstream face of the dam connect to the soil. At this earthquake level, the analysis was completed at 7.28 sec because convergence could not be provided. As a result, structural elements of the dam should be strengthened in the direction of the flow during conservation works for this historical dam. 


\section{REFERENCES}

[1] Lourenço, P.B.: Computational strategies for masonry structures, Ph.D. Thesis, Delft Technical University of Technology, The Netherlands, 1996.

[2] Modena, C., Valluzzi, M.R., Tongini, F.R., Binda, L.: Design choices and intervention techniques for repairing and strengthening of the Monza Cathedral Bell-tower, Construction and Building Materials, 16 (2002), pp. 385-395, https://doi.org/10.1016/ S0950-0618(02)00041-7

[3] Betti, M., Orlando, M., Vignoli, A.: Static behaviour of an Italian Medieval Castle: Damage assessment by numerical modelling, Computers and Structures, 89 (2011), pp. 1956-1970, https://doi. org/10.1016/j.compstruc.2011.05.022

[4] Fanning, P.J., Boothby, T.E.: Three-dimensional modelling and fullscale testing of stone arch bridges, Computers and Structures, 79 (2001), pp. 2645-2662, https://doi.org/10.1016/S00457949(01)00109-2

[5] Bernardeschi, K., Padovani, C., Pasquinelli G.: Numerical modelling of the structural behaviour of Buti's Bell tower, Journal of Cultural Heritage, 5 (2004), pp. 371-378, https://doi.org/10.1016/j. culher.2004.01.004

[6] Karaton, M., Sayın, E., Calayır, Y.: Nonlinear seismic analyses of Malabadi Bridge, Strengthening and preserving historical buildings and cultural heritage-2, 15-17 October, Diyarbakır, Turkey, 2009 (in Turkish).

[7] Bayraktar, A., Șahin, A., Özcan, D., Yıldırım, F.: Numerical damage assessment of Hagia Sophia bell tower by nonlinear FE modelling, Applied Mathematical Modelling, 34 (2010), pp. 92-121, https:// doi.org/10.1016/j.apm.2009.03.033

[8] Sayın, E., Calayır, Y., Karaton, M.: Nonlinear seismic analyses of historical Uzunok Bridge, Seventh National Conference on Earthquake Engineering, 30 May-3 June, İstanbul, Turkey, 2011 (in Turkish).
[9] Gonen, H., Dogan M., Karacasu, M., Ozbasaran, H., Gokdemir, H.: Structural failures in retrofit Historical Murat Masonry Arch Bridge, Engineering Failure Analysis, 35 (2013), pp. 334-342, https://doi.org/10.1016/j.engfailanal.2013.02.024

[10] DLH.: Turkish Seismic Code for Coastal and Harbour Structures, Ministry of Transportation of Turkey, Ankara, 2007 (in Turkish).

[11] Chung, J., Hulbert, G.M.: A time integration algorithm for structural dynamics with improved numerical dissipation: The Generalized- $\alpha$ Method, Journal of Applied Mechanics, 60 (1993), pp. 371, https:// doi.org/10.1115/1.2900803

[12] Manfredi, C., Ramasco, R.: The use of damage functionals in earthquake engineering: a comparison between different methods, Earthquake Engineering and Structural Dynamics, 22 (1993) 10, pp. 855-868.

[13] Rajgelj, S., Amadio, C., Nappi, A.: An internal variable approach applied to the dynamic analysis of elastic-plastic structural systems, Earthquake Engineering and Structural Dynamics, 22 (1993) 10, pp. 885-903.

[14] William, K.J., Warnke, E.P.: Constitutive model for the triaxial behaviour of concrete, Proceeding of the International Association for Bridge and Structural Engineering, 19 (1975), pp. 174-186.

[15] Zeinkiewicz, O.C., Taylor, R.L.: Finite Element Method, Volume 2, McGraw-Hill, 1991.

[16] Calayır, Y., Karaton, M.: Non-linear dynamic analysis of concrete gravity dam via anisotropic damage model: Eularian and Lagrangian approaches, $6^{\text {th }}$ National Conference on Earthquake Engineering, vol-1, pp. 737-748, 16-20 October 2007, Istanbul, Turkey (in Turkish).

[17] Çeçen, K.: Taksim ve Hamidiye Suları, iski Yayınları, İstanbul, 1992 (in Turkish). 